\title{
HeMatological Values of WILD tUCUXI (Sotalia fluViatilis) from the Central Amazon ${ }^{1}$
}

\author{
Daniela M. D. de Mello 2,*, Vera M. F. da Silva ${ }^{2}$ and Anthony Richard Martin ${ }^{3}$
}

Blood analysis is a valuable tool that is routinely applied in assessing the health and physiological status of freeranging animals (Borjesson et al., 2000). However, very few hematological studies have been performed on wild cetaceans, at least partially because of the major logistical difficulties in obtaining samples from such large, mobile, and wholly aquatic animals (St. Aubin et al., 2000). Accidental or intentional entrapments by the commercial fishing industry has granted some opportunities to collect and examine the blood of harbor porpoises (Phocoena phocoena) (Koopman et al., 1999), and beluga whales (Delphinapterus leucas) (St. Aubin et al., 2000), while directed capture and release efforts has resulted in a robust data series for bottlenose dolphins (Tursiops truncatus) (Asper et al., 1990; Goldstein, et al., 2006).

The tucuxi (Sotalia fluviatilis) is endemic and widely distributed throughout the Amazon River Basin. A longterm project involving the capture and release of freshwater dolphins in the Amazon region of Brazil has created a unique opportunity to collect blood samples from wild tucuxis (da Silva and Martin, 2000). The present study reports the first hematological values determined from blood samples taken from two wild adult tucuxis. Comparisons to closely related species were conducted to determine relative blood values. Given the importance of properly storing blood samples taken from wild animals in remote locations, we also present an evaluation of the viability of samples stored at $5^{\circ} \mathrm{C}$ for up to two weeks at a field camp in central Amazonia.

Blood samples were collected at Mamirauá Sustainable Development Reserve $\left(3^{\circ} 3^{\prime} S, 64^{\circ} 51^{\prime} \mathrm{W}\right)$, located in the central Amazon Brazil. The entire seining, handling and release procedure lasted approximately nine minutes and each tucuxi was kept out of the water for a maximum duration of five minutes (da Silva and Martin, 2000). Blood was drawn from the superficial caudal peduncle vessels using a 19-gauge, $1.9 \mathrm{~cm}$ long, butterfly catheter (Becton Dickinson Indústrias Cirúrgicas Ltda., São Paulo, Brazil, 04717-004) and stored at $5^{\circ} \mathrm{C}$ in $5 \mathrm{ml}$ ethylenediaminetetracetic acid (EDTA) Vacutainer tubes (Becton Dickinson Indústrias Cirúrgicas Ltda., São Paulo, Brazil, 04717-004) within six hours from the time of collection. Manual hematological techniques (Delaney and Garratty, 1969) were employed for red blood cells (RBC) and white blood cells (WBC) counts using Hayem and Turck reagents, respectively (Newprov Produtos para Laboratório Ltda., Pinhais, Paraná, Brazil, 83.323-
020). Platelet counts were determined using a salineformalin $40 \%$ solution (Hughes-Jones, 1979), binocular microscope (Nikon E-200, Nikon Instruments Inc., N.Y. 11747-3064, U.S.A.), and a Neubauer-Improved counting chamber (LO - Laboroptik $\mathrm{GmbH}$, Friedrichsdorf, Germany). Microhematocrit capillary tubes were centrifuged at $12,850 \times \mathrm{G}$ for $10 \mathrm{~min}$ and inspected against a standard calibration to determine packed cells volume (PCV). Samples for hemoglobin $(\mathrm{Hb})$ analysis were prepared by pipetting $20 \mu \mathrm{l}$ whole blood into $5 \mathrm{ml}$ Drabkim's reagent (Newprov Produtos para Laboratório Ltda., Pinhais, Paraná, Brazil, 83.323-020) for subsequent photometric determination (Lima et al., 1992). Erythrocyte cell indices were calculated by mean cell volume $(\mathrm{MCV})(\mathrm{fl})=\operatorname{PCV}(\%) \times 10 / \mathrm{RBC}\left(10^{6} / \mathrm{mm}^{3}\right)$ and by mean cell hemoglobin concentration $(\mathrm{MCHC})(\mathrm{g} / \mathrm{dl})$ $=\mathrm{Hb}$ concentration $(\mathrm{g} / \mathrm{dl}) / \mathrm{PCV}(\%)$. Blood smears were treated with Wright's staining solution (Laborclin Produtos para Laboratório Ltda., Pinhais, Paraná, Brazil, 83.321-210) to conduct differential counts of 100 WBC per slide. Analyses of blood stored for 7 and 14 days were all performed using the same samples and methodology in order to evaluate possible changes in hematological values over time.

Comparisons to 59 wild T. truncatus from Indian River Lagoon, Florida, and nine healthy Guiana dolphins (Sotalia guianensis) maintained for at least four months in captivity at European dolphinaria, were also performed as an attempt to identify possible diversity of common blood values among several species (Goldstein et al., 2006; van Foreest, 1980).

Despite the low number of individuals in the present study $(\mathrm{n}=2)$, a few differences occurred between wild freshwater and marine Sotalia species, although hematological values were very similar overall (Table 1 ). While PCV and $\mathrm{Hb}$ appear to be slightly higher in wild specimens, the RBC and MCV values fall outside the range estimated for samples from captive individuals. These observations may reflect changes due to certain conditions of their very different environments or be a result of stress in captivity influencing blood values. Previous studies have shown that captive common seals (Phoca vitulina) have consistently lower levels of the same blood component values (PCV, $\mathrm{RBC}$, and $\mathrm{Hb}$ ) compared to wild seals and attributed these observations to decreased activity caused by limited space and water depth in captive conditions (McConnell and Vaughan, 1983).

\footnotetext{
${ }^{1}$ Received on 29 April 2009. Accepted on 29 December 2009. Managed by Daniel Palacios.

${ }^{2}$ Laboratório de Mamíferos Aquáticos, Instituto Nacional de Pesquisas da Amazônia, Avenida André Araújo, 2936, CP 478, Petrópolis, 69011-790 Manaus, Amazonas, Brazil.

${ }^{3}$ Durrell Institute for Conservation and Ecology, University of Kent, Canterbury Kent, CT2 7NR, United Kingdom.

* Corresponding author, e-mail: danielamello@hotmail.com.
} 
Comparison of the values for Sotalia spp. to wild $T$. truncatus reveals that RBC values are still higher in $S$. fluviatilis, suggesting an interspecific difference rather than an effect of environmental conditions. All values estimated for $S$. fluviatilis fall within the ranges of values estimated for $S$. guianensis, although some differences were observed with respect to the WBC differential count. Again, it is difficult to conclude whether or not these differences are the result of conditions in captivity or simply a reflection of interspecific variation, especially considering that the antigenic stimulation of these three species is probably very different and promotes the production of distinctly different types of WBC.

Comparisons of seven hematological values between fresh and stored refrigerated blood (7 and 14 days) revealed important changes in all parameters (Table 2). While RBC, WBC and platelets values decreased during storage, values of $\mathrm{PCV}, \mathrm{Hb}, \mathrm{MCV}$ and $\mathrm{MCHC}$ all showed small increases. The observed decrease in values of RBC, WBC and platelets are all due to the effects of cell lysis that occurs naturally in stored blood. The most significant decrease occurred between the first and seventh days for RBC, $36.6 \%$ in tucuxi A and $17 \%$ in tucuxi B. WBC showed a decrease of $14.4 \%$ between the first and seventh day and $20 \%$ between the seventh and $14^{\text {th }}$ day in tucuxi $\mathrm{A}$, and $23.7 \%$ between the first and seventh day and $26.5 \%$ between the seventh and $14^{\text {th }}$ day in tucuxi B. Platelets showed a more pronounced decrease $(58.3 \%)$ between the seventh and $14^{\text {th }}$ day in tucuxi $\mathrm{A}$ and between the first and seventh day (36.1\%) in tucuxi B. While hematological values noticeably decreased over time, no patterns allowing for more precise inference regarding cell decrease with respect to time of storage prior to analysis emerged.

We observed that stored blood samples became browner and darker over time, promoting interferences in light measurements by spectrophotometry, but falsely increasing measurements of hemoglobin concentration and consequently increasing estimates of MCHC values. Slight increases in PCV, due to erroneous measurements caused by hemolysis and combined with decreasing RBC estimates, gave the false impression of increases in $\mathrm{MCV}$. Hemoglobin concentration showed the largest increase $(18 \%)$ between the seventh and $14^{\text {th }}$ day in tucuxi B. MCV increased $62 \%$ and $\mathrm{CHCM}$ increased $5 \%$ between the seventh and $14^{\text {th }}$ day in tucuxi $\mathrm{A}$.

Table 1. Hematological values from two wild adult male Sotalia fluviatilis, mean and range values from nine captive S. guianensis (van Foreest, 1980) and mean, SD and range from 59 wild T. truncatus (Goldstein et al., 2006).

\begin{tabular}{|c|c|c|c|c|}
\hline HEMATOLOGICAL VALUES & $\begin{array}{c}\text { Sotalia } \\
\text { fluviatilis (A) }\end{array}$ & $\begin{array}{c}\text { Sotalia } \\
\text { fluviatilis (B) }\end{array}$ & $\begin{array}{l}\text { Sotalia } \\
\text { guianensis }\end{array}$ & $\begin{array}{l}\text { Tursiops } \\
\text { truncatus }\end{array}$ \\
\hline PCV (\%) & 42 & 43 & $\begin{array}{c}40.5 \\
(38-43)\end{array}$ & $\begin{array}{c}40 \pm 2.41 \\
(35-46)\end{array}$ \\
\hline $\mathrm{RBC}\left(10^{6} / \mathrm{mm}^{3}\right)$ & 5.98 & 5.16 & $\begin{array}{c}4.27 \\
(3.74-4.98)\end{array}$ & $\begin{array}{c}3.61 \pm 0.28 \\
(2.8-4.8)\end{array}$ \\
\hline $\mathrm{Hb}(\mathrm{g} / \mathrm{dl})$ & 15.85 & 14.36 & $\begin{array}{c}13.4 \\
(12.9-14.5)\end{array}$ & $\begin{array}{c}14.47 \pm 1.11 \\
(11.3-18.2)\end{array}$ \\
\hline $\operatorname{MCV}(\mathrm{fl})$ & 70 & 83 & $\begin{array}{c}94 \\
(86-101)\end{array}$ & $\begin{array}{c}112.2 \pm 6.46 \\
(96-126)\end{array}$ \\
\hline $\mathrm{MCHC}(\mathrm{g} / \mathrm{dl})$ & 37 & 33 & $\begin{array}{c}33 \\
(34-40)\end{array}$ & $\begin{array}{c}35.93 \pm 1.01 \\
(32-38)\end{array}$ \\
\hline $\mathrm{ESR}^{\mathrm{a}}$ (mm/hour) & 60 & 42 & $\mathrm{ND}^{\mathrm{b}}$ & $\mathrm{ND}^{\mathrm{b}}$ \\
\hline Platelets $\left(10^{3} / \mathrm{mm}^{3}\right)$ & 240 & 144 & $\mathrm{ND}^{\mathrm{b}}$ & $\begin{array}{c}167.12 \pm 41.68 \\
(73-281)\end{array}$ \\
\hline WBC $\left(10^{3} / \mathrm{mm}^{3}\right)$ & 10.8 & 15.6 & $\begin{array}{c}9.16 \\
(5.7-14.1)\end{array}$ & $\begin{array}{c}10.31 \pm 2.58 \\
(5.8-19.5)\end{array}$ \\
\hline Neutrophil (\%) & 51 & 48 & $\begin{array}{c}56.5 \\
(40-80)\end{array}$ & $\begin{array}{c}44.55 \pm 9.89 \\
(25.3-68.4)\end{array}$ \\
\hline Band neutrophil(\%) & 0 & 2 & $\begin{array}{c}0.5 \\
(0-2)\end{array}$ & $\begin{array}{c}0.04 \pm 0.31 \\
(0-2.41)\end{array}$ \\
\hline Lymphocyte (\%) & 40 & 38 & $\begin{array}{c}27 \\
(13-47)\end{array}$ & $\begin{array}{c}19.29 \pm 7.8 \\
(2.04-47.33)\end{array}$ \\
\hline Monocyte (\%) & 2 & 4 & $\begin{array}{c}2.5 \\
(1-5)\end{array}$ & $\begin{array}{c}3.29 \pm 2.24 \\
(0-10.69)\end{array}$ \\
\hline Eosinophil (\%) & 7 & 8 & $\begin{array}{c}13.5 \\
(7-22)\end{array}$ & $\begin{array}{l}32.4 \pm 9.28 \\
(13.7-52.8)\end{array}$ \\
\hline Basophil (\%) & 0 & 0 & $\begin{array}{c}0 \\
(0-2)\end{array}$ & $\begin{array}{c}0.04 \pm 0.08 \\
(0-0.3)\end{array}$ \\
\hline
\end{tabular}

$\left(\right.$ ESR $\left.^{\mathrm{a}}\right)$ Erythrocyte sedimentation rate; $\left(\mathrm{ND}^{\mathrm{b})}\right.$ Not determined. 
Table 2. Effect of time on hematological values in blood samples from two wild adult male Sotalia fluviatilis, fresh and stored for 7 and 14 days at $5^{\circ} \mathrm{C}$.

\begin{tabular}{|c|c|c|c|c|c|c|c|c|}
\hline & TIME & $\begin{array}{c}\text { PCV } \\
(\%)\end{array}$ & $\begin{array}{c}\text { RBC } \\
\left(10^{6} / \mathrm{mm}^{3}\right)\end{array}$ & $\begin{array}{c}\mathrm{Hb} \\
(\mathrm{g} / \mathrm{dl})\end{array}$ & $\begin{array}{l}\text { MCV } \\
(\mathrm{fl})\end{array}$ & $\begin{array}{l}\text { MCHC } \\
(\mathrm{g} / \mathrm{dl})\end{array}$ & $\begin{array}{c}\text { WBC } \\
\left(10^{3} / \mathrm{mm}^{3}\right)\end{array}$ & $\begin{array}{l}\text { Platelets } \\
\left(10^{3} / \mathrm{mm}^{3}\right)\end{array}$ \\
\hline \multirow{3}{*}{$\begin{array}{l}\text { Sotalia fluviatilis } \\
\text { (A) }\end{array}$} & Day 0 & 42 & 5.98 & 15.81 & 70.23 & 37.64 & 10.8 & 240 \\
\hline & Day 7 & 43 & 3.77 & 16.99 & 114.05 & 39.51 & 9.25 & 192 \\
\hline & Day 14 & 44 & 3.64 & 18.50 & 120.88 & 42.04 & 7.40 & 80 \\
\hline \multirow{3}{*}{$\begin{array}{l}\text { Sotalia fluviatilis } \\
\text { (B) }\end{array}$} & Day 0 & 43 & 5.16 & 14.36 & 83.36 & 33.39 & 15.6 & 144 \\
\hline & Day 7 & 44 & 4.28 & 16.18 & 102.80 & 36.77 & 11.9 & 92 \\
\hline & Day 14 & $\mathrm{ND}^{\mathrm{a}}$ & 4.27 & 19.12 & $\mathrm{ND}^{\mathrm{a}}$ & $\mathrm{ND}^{\mathrm{a}}$ & 8.75 & 64 \\
\hline
\end{tabular}

(ND) Not determined.

Changes in MCV between the seventh and $14^{\text {th }}$ day were not so pronounced in tucuxi B, showing an increase of $23 \%$, and $10 \%$ in CHCM. PCV of tucuxi B could not be estimated from the seventh day samples due to a high degree of hemolysis and, consequently, MCV and MCHC could not be calculated. Blood samples from tucuxi showed great sensitivity to storage time, even when maintained in a continuously refrigerated state, and should be analyzed within 24 hours from the time of collection to achieve the most accurate estimates of hematological values possible.

There is a clear and urgent need for reliable, representative baseline hematological value data from wild Sotalia spp. for long-term population monitoring. The value estimates reported here are from only two individuals and do not represent statistically valid normal ranges, and thus should be used with caution. However, these data do provide important preliminary estimates of blood values for wild S. fluviatilis and will be useful in future conservation efforts.

\section{Acknowledgments}

We are very grateful to all people involved in the capture, restraint and blood collection of the animals used in this work. This work was carried out under successive permits granted to VMFS by IBAMA/SISBIO (Brazilian National Environmental Agency) and satisfied its criteria on ethics and animal welfare. We thank Instituto Mamirauá and the financial sponsors of Projeto Boto for their continued support of this long-term project, and funding from Conselho Nacional de Desenvolvimento Científico e Tecnológico (CNPq) and Instituto Nacional de Pesquisas da Amazônia (INPA). We also thank Dr. Heather Koopman and an anonymous reviewer for their helpful comments during the review process of the manuscript.

\section{References}

Asper, E.D., Cornell, L.H., Duffield, D.A., Odell, D.K., JosePh,
B.E., Stark, B.I. And Perry, C.A. (1990) Hematology and serum chemistry values in the bottlenose dolphins. Pages 479-485 in Leatherwood, S. and Reeves, R.R. (Eds) The Bottlenose Dolphin. Academic Press, San Diego, California, EUA.

Borjesson, D.L., Christopher, M.M. And Boyce, W.M. (2000) Biochemical and hematologic reference intervals for free-ranging desert bighorn sheep. Journal of Wildlife Diseases 36: 294-300.

DA SILVA, V.M.F. AND MARTIN, A.R. (2000) A study of the boto, or Amazon River dolphin (Inia geoffrensis), in the Mamirauá Reserve, Brazil: operation and techniques. Pages 121-131 in REEVES, R.R., SMITH, B.D. AND KasUYA, T. (Eds) Biology and conservation of freshwater cetaceans in Asia Occasional paper of the IUCN Species Survival Commission No 23. Gland, Switzerland: IUCN.

Delaney, J.W. and Garratty, G. (1969) Handbook of Haematological and Blood Transfusion Techniques. Whitefriars Press, London and Tonbridge, Great Britain.

Goldstein, J.D., Reese, E., Reif, J.S., Varela, R. A., McCulloch, S.D., Defran, R.H., Fair, P.A. and Bossart, G.D. (2006) Hematologic, biochemical and cytologic findings from clinically healthy Atlantic bottlenose dolphins (Tursiops truncatus) inhabiting the Indian River Lagoon, Florida, USA. Journal of Wildlife Diseases 42(2): 447-454.

Hughes-Jones, N.C. (1979) Lecture Notes on Haematology. $3^{\text {rd }}$ ed. Blackwell Science Ltd, Oxford, UK.

Koopman, H.N., Westgate, A.J. and Read, A.J. (1999) Hematology values of wild harbor porpoises (Phocoena phocoena) from the Bay of Fundy, Canada. Marine Mammal Science 15(1): 52-64.

Lima, A.O., Soares, J.B., Greco, J.B., GalizzI, J. and Cançado, J.R. (1992) Métodos de Laboratório Aplicados à Clínica - Técnica e Interpretação. Guanabara Koogan, Rio de Janeiro, Brazil.

McConnelL, L.C. AND Vaughan, R.W. (1983) Some blood values in captive and free-living common seals (Phoca vitulina). Aquatic Mammals 10(1): 9-13.

St. Aubin, D.J., Deguise, S., Richard, P.R., Smith, T.G. ANd Geraci, J.R. (2000) Hematology and plasma chemistry as indicators of health and ecological status in beluga whales, Delphinapterus leucas. Artic 54(3): 317-331.

VAN Foreest, A.W. (1980) Hematologic findings in Sotalia fluviatilis guianensis. Aquatic Mammals 8(1): 15-18. 